\title{
Combinatoria léxica y caracterización semántica del verbo andar en el siglo XIII*
}

\author{
Lexical combination and semantic characterization \\ of the verb andar in the $13^{\text {th }}$ century
}

Ana Paz Afonso

Universitat Autònoma de Barcelona

RESUMEN: Si bien algunas investigaciones han advertido acerca de la importancia de los verbos de movimiento en la lengua de los orígenes, son escasos los que han dedicado un estudio monográfico al verbo andar. El propósito de este trabajo es precisamente poner de relieve las características más importantes de esta unidad lingüística en el siglo XIII, etapa clave en el proceso de elaboración de la lengua escrita en romance. Mediante el análisis de las restricciones semánticas existentes sobre la selección léxica de los argumentos de andar, se ha establecido una clasificación de los usos de este verbo, poniendo de manifiesto la utilidad de una perspectiva combinatoria en el estudio diacrónico e histórico del léxico.

Palabras clave: semántica histórica, combinatoria léxica, diacronía, verbo andar.

ABSTRACT: While some studies have discussed the importance of verbs of motion in the earliest stages of the Spanish language, there are few that have devoted a research monograph to the verb andar. The purpose of this article is to highlight the most important features of this linguistic unit in the $13^{\text {th }}$ century, a key stage in the development process of the written language in Romance. By analyzing the existing semantic

* El presente artículo ha sido posible gracias a la ayuda de la DGICYT para el proyecto "Portal de léxico hispánico: bibliografía, léxico y documentación” (FFI2008-06324-c02-01) y a una beca predoctoral del Comissionat per a Universitats $i$ Recerca del Departament d'Innovació, Universitats i Empresa de la Generalitat de Catalunya y del Fons Social Europeu. Asimismo, también se ha podido llevar a cabo gracias al apoyo del Comissionat per a Universitats $i$ Recerca para el proyecto "Grup de lexicografia i diacronia" (2009SGR1067). Quiero expresar mi agradecimiento a Gloria Clavería Nadal y a Carolina Julià Luna por sus comentarios y observaciones. 
constraints on the arguments of andar's lexical selection, a classification of the uses of this verb has been established showing the advantages of the combinatorial approach in the diachronical and historical study of the lexicon.

Keywords: historical semantics, lexical combinations, diachrony, verb andar.

\section{INTRODUCCIÓN}

En los últimos treinta años, el estudio histórico y diacrónico de los verbos de movimiento ha progresado significativamente, reconociéndose así la importancia de este tipo de palabras en la lengua. No obstante, no todas las unidades lingüísticas pertenecientes a este campo léxico han sido igualmente estudiadas. Determinadas voces, más propensas por sus características aspectuales o sintáctico-semánticas a experimentar cambios lingüísticos, se han convertido de forma recurrente en el centro de atención de investigaciones históricas y diacrónicas, como es el caso de ir o venir (vid. Pérez Saldanya, 2008; Martín Zorraquino, 1993, 1998). Por el contrario, otras palabras también vinculadas a la noción de movimiento han permanecido en un segundo plano, siendo objeto únicamente de aproximaciones esporádicas o superficiales.

$\mathrm{Si}$ bien es cierto que algunos trabajos previos han advertido acerca de la importancia de los verbos de movimiento en los orígenes del romance (vid. Castillo, 2003; Crego, 1994, 1998, 2002; Eslava, 2008; Galán, 1988; Paz, 2010, 2013, en prensa a, en prensa b; Serradilla, 2011; Suárez Fernández 1992), son escasos los que han dedicado un estudio monográfico a andar (vid. Behrens, 1902; García Padrón 1990; Meier, 1933; Paz, 2008, 2009; Rice, 1904; Roca, 1954; Sánchez Jiménez, 2011), unidad que ha dado lugar a construcciones, interjecciones y expresiones de gran éxito en la lengua actual. Se trata, además, de una palabra patrimonial, por lo que puede considerarse una valiosa pieza léxica del sistema lingüístico.

Por todas estas razones, el estudio aquí presentado tiene como objetivo realizar una caracterización del verbo andar a través del análisis de sus restricciones léxicas sobre la selección argumental, con la finalidad de conocer cuáles y de qué tipo son las relaciones que mantiene este predicado con sus argumentos y establecer los vínculos existentes entre estas palabras y los valores semánticos que presenta andar ${ }^{1}$. No obstante, la complejidad de esta voz obliga a delimitar cronológicamente el periodo analizado, siendo el siglo XIII la etapa escogida

\footnotetext{
${ }^{1}$ El artículo de García Padrón (1990) constituye un referente para este trabajo en tanto que se basa en unas premisas similares, si bien, a diferencia de la presente investigación, centra el estudio del verbo andar en el español actual.
} 
por dos motivos; por un lado, es la época más antigua que ofrece un número suficientemente significativo de documentaciones, y, por otro, se trata de un momento clave en la historia y evolución del español debido a la generalización de la norma romance.

Partiendo de las informaciones del Corpus Diacrónico del Español (CORDE), las primeras documentaciones del verbo andar, incluyendo sus posibles variantes gráficas, se remontan a los años 950-1000 aproximadamente, aunque entre ese periodo y 1200 únicamente se registran 81 ocurrencias. Sin embargo, a partir del siglo XIII su presencia aumenta sensiblemente hasta alcanzar un total de 10.193 concordancias.

Todas estas documentaciones se concentran en un total de 581 obras repartidas en diferentes tradiciones discursivas. La mayor parte pertenece a crónicas (46.3\%), a documentos notariales de diversa naturaleza (13.2\%) (actas, cartas de venta, privilegios, pleitos, fallos, cartas de donaciones, sentencias, testamentos o cartas de exención, entre muchos otros) y a códigos legislativos como fueros, ordenamientos o normas (11.04\%). No obstante, aunque en menor medida, el verbo andar aparece también en poemas del mester de clerecía (7.6\%), cuentos, exempla y castigos $(6.8 \%)$, biblias romanceadas $(6.7 \%)$, obras científicas $(3.2 \%)$, tratados enciclopédicos, de agricultura, astrología, caza, cetrería y veterinaria $(2.9 \%)$, obras hagiográficas $(1.3 \%)$, libros de juegos $(0.6 \%)$, cancioneros religiosos $(0.3 \%)$, plantos $(0.2 \%)$ y poemas aljamiados $(0.03 \%)$.

Es imprescindible prestar atención a la selección semántica de un predicado para comprender en profundidad su funcionamiento. No obstante, son poco comunes los estudios que se centran en el análisis de la selección semántica verbal en las primeras etapas del romance (vid. Paz, 2008, en prensa b), si bien algunos, como los de García Pérez (2003-2004, 2005, 2007), han tratado esta cuestión desde un punto de vista lexicográfico. Resulta particularmente productiva la propuesta de Bosque (2004), que parte del análisis de los predicados en lugar del de los argumentos. La aplicación de esta metodología al estudio de andar en el siglo XIII facilita el acometimiento de dos cuestiones principales: la manera en que este verbo restringe a sus argumentos y cómo se relacionan los usos físicos con los figurados. Por esa razón, en las siguientes páginas, las palabras seleccionadas por el predicado andar se han agrupado conceptualmente en clases léxicas etiquetadas en paréntesis angulares en función de aquello que designan ${ }^{2}:<$ accio- $^{-}$ nes $>$, <autoridad $>$, <conflictos $>$, <entidades abstractas $>$, <estados físicos o psicológicos $>$, $<$ faltas $>$, <objetos físicos y lugares $>$, $<$ partes del cuerpo $>$, $<$ periodos temporales $>$ y $<$ seres materiales e inmateriales $>$.

Asimismo, todo estudio linguiístico de tipo histórico o diacrónico requiere

\footnotetext{
${ }^{2}$ Posiblemente podrían elaborarse clasificaciones alternativas; sin embargo, las que se plantean se justifican por la presencia de rasgos léxicos compartidos por sus integrantes.
} 
de una mínima contextualización histórica y cultural con el fin de comprender los factores externos que han condicionado el desarrollo de la lengua. Por ese motivo, antes de iniciar el análisis de las documentaciones se procederá a destacar las características históricas y lingüísticas más relevantes del siglo XIII.

\section{LA IMPORTANCIA DEL SIGLO XIII EN LA HISTORIA DEL ROMANCE}

La coexistencia de la norma romance con la latina fue una constante desde el siglo VIII hasta el XII (Bustos Tovar, 2005: 268), si bien el uso de la última era más frecuente en los textos que manifestaban una mayor distancia comunicativa ${ }^{3}$.

El primer paso del castellano hacia su estatus como lengua de cultura se inició durante el reinado de Fernando III (1230-1252), en el que se empezaron a emitir escritos oficiales de la cancillería real en lengua vernácula. Posteriormente, a través de la labor de su scriptorium, Alfonso X consiguió que estuviera presente también en la producción cultural y científica mediante la traducción de obras sobre astronomía, matemáticas y otras disciplinas (Bossong, 1982: 2). Como consecuencia, el número de géneros en que intervenía se multiplicó a través de la imitación de las tradiciones discursivas extranjeras, especialmente árabes, latinas y hebreas ${ }^{4}$ (Galmés, 1985: 35-37).

Todo ello implicó que el castellano se viera forzado a desarrollar los mecanismos necesarios para expresar conceptos e informaciones tanto del mundo material como del mundo espiritual (Galmés, 1985: 37), enriqueciendo así su léxico, su sintaxis y aumentando la coherencia textual, aproximándolo así a las lenguas propias de la distancia comunicativa (Koch y Oesterreicher, 2007: 200; Lapesa, 2008 [1981]: 209, 216).

\section{ORÍGENES DEL VERBO ANDAR}

El verbo andar, como suele ocurrir con el léxico patrimonial, presenta una evolución semántica y formal destacable desde el latín hasta la generalización

\footnotetext{
${ }^{3}$ Los conceptos de distancia e inmediatez comunicativa han sido tomados de Peter Koch y Wulf Oesterreicher (2007). El primero hace referencia al nivel más próximo a la lengua empleada en los textos escritos, mientras que el segundo se refiere a la lengua hablada, dando lugar de esta forma a dos extremos unidos por un continuum. Por tanto, un texto puede acercarse más a uno o a otro en función de sus características. Esta posibilidad se ajusta más adecuadamente a la realidad de la lengua que la teoría tradicional que contraponía la oralidad a la escritura como conceptos bipolares sin posibilidad de alcanzar un término medio.

${ }^{4}$ Para más información acerca de la política lingüística de Fernando III y Alfonso X, vid. Hernández Navarro (1999: 133), Fernández-Ordóñez, (2005: 382-383) y González Ollé (1978: 234-235).
} 
de las lenguas vernáculas. Con la finalidad de realizar una adecuada caracterización de los usos linguiísticos de este verbo en el siglo XIII, creemos conveniente dejar constancia de las características semánticas de su étimo latino.

\subsection{Procedencia etimológica}

Los estudios que han tratado de dilucidar la procedencia etimológica de andar y su evolución hasta su aspecto formal actual se caracterizan, en líneas generales, por ser investigaciones de tipo comparativo que exploran esta cuestión desde una óptica panrománica (vid. Behrens, 1902; Malkiel, 1947; Rohlfs, 1920; REW s. v. AMBŬLARE; Rice, 1904; Schuchardt, 1902; FEW, s. v. AMBŬLARE). Se ha constatado que en latín vulgar se produjo una serie de cambios en el paradigma de los verbos de movimiento (Väänänen, 2003: 132-133), que se manifestaron posteriormente en todas las lenguas románicas ${ }^{5}$.

En esa etapa del latín pueden identificarse diferentes variantes de un mismo étimo: AMBULĀRE. En el norte de la Galia la forma propia de esa zona era alare — quizá *allare —, mientras que en el sur predominaría *annare y en España e Italia, *andare (Grandgent, 1963: 247). Con el paso del tiempo y la fuerza del uso, este étimo inicial se iría transformando en latín vulgar hasta llegar a la forma *amlare, que constituiría el estadio previo al actual andar (DECH, s. v. andar).

Son muchas las aportaciones que se han llevado a cabo sobre los valores semánticos de AMBULĀRE. En el $F E W$ (s. v. AMBŬLARE) se indica que está formado por el prefijo $a m b$ - 'alrededor' y que se trataba de una palabra propia de la lengua popular o familiar que terminó por generalizarse. Según Gaffiot (1934, s. v. AMBULO), este étimo significaba 'ir y venir, andar de un lado para otro, circular, pasear; andar, caminar; pasar, ir de mano en mano'. En el $R E W$ (s. v. AMBǓLARE) aparece también la acepción 'ir', que Grandgent (1963: 27) corrobora citando textos de Cicerón, en los que éste ya utilizaba AMBŬLARE con ese significado. Asimismo, añade los significados 'marchar' y 'continuar' como extensiones semánticas generadas en latín vulgar. Por su parte, Gaffiot (1934: $s . v$. AMBULO) aporta un dato interesante, ya que señala que en latín AMBǓLARE podía seleccionar argumentos externos ${ }^{6}$ [- humanos], como nave o río. Se trata de una particularidad destacable, puesto que implica la existencia de procesos de metaforización y metonimización anteriores a la evolución romance.

\footnotetext{
${ }^{5}$ Estas alteraciones pueden apreciarse claramente en el caso del francés aller, cuya conjugación actual es fruto de una amalgama morfológica de los verbos latinos IRE 'ir', VADERE 'venir' y AMBULĀRE 'andar' (DHLF, s. v. aller). Véanse las demás formas románicas equivalentes, como el italiano andare, el portugués andar, el catalán y occitano anar, el francés aller, el rumano umbla, el friulano la o el macedo-rumano îmnare (DECH, s. v. andar).

${ }^{6}$ En adelante, AE.
} 
En definitiva, el étimo latino de andar era una unidad léxica que podía ser utilizada como verbo [+ direccional] y [-direccional], ya que en algunos significados estaban presentes estos rasgos mientras que en otros no ocurría lo mismo, circunstancia que tendrá repercusiones en el desarrollo en romance de este predicado.

\subsection{El verbo andar en los orígenes del romance castellano: siglos VIII-XII}

Las dos primeras documentaciones del verbo andar en el CORDE se corresponden con ambulare, una forma con rasgos latinizantes de una carta de donaciones del año 972, y con andat, que aparece en las Glosas Silenses. Sin embargo, las ocurrencias de este verbo escasean entre los siglos X y XI, localizándose algo más de una decena de ejemplos en el CORDE en los que conviven tanto las formas romanceadas como las que conservan características del latín.

Antes del siglo XIII, andar presentaba ya unos valores semánticos que no se limitaban a su empleo como verbo de movimiento, sino que había desarrollado otros significados figurados en función del contexto que lo acompañaba (Paz, 2008: 13-24). No obstante, no es hasta este siglo cuando experimenta la primera ampliación y diversificación de sus valores semánticos.

Entre los significados ligados al movimiento, se encuentran 'moverse dando pasos, caminar', 'desplazarse', 'ir' y 'marcharse'. El primero de ellos (1) ya era un valor propio del étimo latino AMBULĀRE y es el que concentra el mayor número de ocurrencias?

1. Ipse autem rex cum suo exercitu intravit per Portum Regem in terram Moabitarum, et alius exercitus cum comité Roderico Gunzalvi intravit per Protum de Muradal; et ambulaverunt quindecim diebus per eremum (CORDE, Anónimo, Chronica Adefonsi Imperatoris, c1160).

'Desplazarse', por su parte, comienza a aparecer con cierta asiduidad en el corpus a partir de la segunda mitad del siglo XII (2), mientras que 'ir', a pesar de ser un significado que ya se encontraba presente en el étimo latino, no es tan recurrente (3). Por último, el significado 'marcharse' (4) se encuentra de manera esporádica entre los siglos VIII y XII.

2. Dono et concedo spontanea voluntate ad ecclesiam Ihesu Nazareno de Mont Aragon et ad ecclesia sancto Iacobo de Funes uno pontone per piscare

\footnotetext{
${ }^{7}$ La perífrasis pensar de andar aparece frecuentemente en el Cid. Según las notas críticas de Alberto Montaner (2000: 48), tal construcción tiene el valor incoativo de 'ponerse en marcha', idea que ya señaló Yllera (1980: 186). Otra construcción de significado similar es meterse a andar, aunque únicamente se encuentra de manera esporádica en el siglo XII según los datos del CORDE.
} 
quod andet et vadat per Arga et per Aragone et per Ebro unde se querit (CORDE, Anónimo, Pedro I concede a Montearagón y a Santiago de Funes un pontón para que puedan pescar en los ríos Arga, Aragón y Ebro y licencia para construir un cañar, 1103).

3. Seniores, a qual tirra, o que[redes] andar? Queredes ir conmigo al Criador rogar? (CORDE, Anónimo, Auto de los Reyes Magos, c1180).

4. Mulier qui laxauerit suo marido et cum alio se ambulauerit, hereditet suum maritum omnia sua omnibus diebus uite sue (CORDE, Anónimo, Fuero de Uclés, 1179-1184).

Asimismo, el verbo andar presenta otros usos ajenos al movimiento físico, como son 'actuar dejándose llevar por alguien o algo o bajo su mandato' (5) o 'actuar en beneficio o en contra de algo o alguien' (6), significados que aparecen en testimonios tempranos y que se conservan durante el siglo XIII.

5. Mulier que lenocinium [ena cemajacione meretrize] exercuerit [facet andat $]$ idest que corpus suum alieno uendiderit, nec in finem acciperet debet communionem (CORDE, Anónimo, Glosas Silenses, c950-1000).

6. Dezid a Ruy Díaz, el que en buen ora nació, que l'ire a vistas do aguisado fuere; fo él dixiere, ý sea el mojón; andarle quiero a mio Cid en toda pro (CORDE, Anónimo, Cantar de Mio Cid, 1140).

'Transcurrir un periodo de tiempo' es un valor semántico cuya presencia va en aumento, especialmente en documentos de tradiciones discursivas como los fueros o las cartas de venta. Aunque andar se utilizaba para indicar cualquier tipo de referencia temporal en el cuerpo del texto (7), también eran habituales ciertas fórmulas para indicar la fecha en la que fueron redactados (8) (vid. Paz 2008: 20, 28-30; 2010: 371-375), lo que favorece el incremento del número de ocurrencias a medida que la estructura se va fijando en las tradiciones discursivas en las que aparece.

7. Como quier quelos querellosos por costrenjmjento de plazos $\&$ de peyndra alcançan derecho de sus contendedores, son dias \& oras \& tiempos sennalados que por reuerençia de Dios [...] njnguno non deue seer peyndrado en ellos [...] Et son estos: [...] del dia de sant Miguell fasta las tres semanas andadas de octubre por razon delas uendimjas (CORDE, Anónimo, Fuero de Soria, c1196).

8. Fecha la carta dos días por andar de setiembre, era de mill años (CORDE, Anónimo, Carta de entrega de unos bienes, c1162).

Finalmente, se documentan muestras de gramaticalización del verbo andar en los significados 'encontrarse en un determinado estado' —utilizado junto a adjetivos y participios - y 'encontrarse realizando una determinada acción' - junto a gerundios_- donde funciona como auxiliar. Este tipo de uso es cada vez más habitual a medida que las documentaciones se aproximan al siglo XIII. 
9. Non pudieron ellos saber la cuenta de todos los cavallos que andan arriados e non ha qui tomallos; los moros de las tierras ganado se an ý algo (CORDE, Anónimo, Cantar de Mio Cid, 1140).

10. Njnguno que non fuere de hedat, nj traydor [...], nj omne de orden que ande desobedient, [...] non ssea rreçebido por firma empleyto njnguno (CORDE, Anónimo, Fuero de Soria c1196).

11. Nos supra memorati Munnio, Johannes, Abdella, don Zahet, Martino, qui hanc cartulam vendicionis fieri iussimus et legendo andivimus, coram testibus ad roborandum tradimus (CORDE, Anónimo, Los barones de San Esteban de Gormaz venden a Arlanza una aceña sita en el puente de dicha población, 1068).

\section{CARACTERIZACIÓN SEMÁNTICA DEL VERBO ANDAR EN EL SIGLO XIII}

En el siglo XIII el número de documentaciones aumenta de manera espectacular respecto al de los siglos anteriores, en gran medida debido a los factores históricos y culturales expuestos previamente ( $\$ 2$ ). Asimismo, existe una mayor variedad en los usos semánticos de andar, que pueden ser organizados en tres categorías: usos físicos, usos figurados y usos como verbo gramaticalizado o en proceso de gramaticalización.

\subsection{Usos físicos de andar}

El empleo de andar como verbo de movimiento es el esencial de este predicado, que adopta diversos significados para hacer referencia a cambios de posición o desplazamientos en el espacio: 'moverse dando pasos, caminar', 'desplazarse', 'recorrer un espacio físico', 'moverse por las casillas de un tablero' e ‘ir'.

\subsection{1. 'Moverse dando pasos, caminar'}

Cuando andar selecciona un AE que designa a un ser material o inmaterial [+animado], éste suele ser un ser humano, como alcalde, caballero, cojo, compaña, conde, hijo, hombre, infantes, Jesucristo, María, niña, nos, pastor, querelloso, rey, tú o varón, por ejemplo.

12. El conde don Fernando non podía andar, ovo l' ella un poco a cuestas a llevar". (CORDE, Anónimo, Poema de Fernán González, c1250).

13. Moça, a ti digo quet leuantes. E leuantos luego la ninna, e andaua (CORDE, Anónimo, El Nuevo Testamento según el manuscrito escurialense $I-j-6$, a1260). 
No obstante, también puede seleccionar sustantivos que hacen referencia a animales, como animalias, buey, gamo, ganado, perdiz o pescado.

14. E de las mezclas de las animalias que se mueven e andan vos avemos ya departido, como oyestes (CORDE, Alfonso X, General Estoria. Primera parte, $\mathrm{c} 1275)$.

15. Et otrossi mando que los sus bueyes anden e pazcan alli do andan los mios de la lavor (CORDE, Anónimo, Privilegio de Alfonso X, 1272).

El significado que adopta andar en ambos casos es el de 'moverse dando pasos, caminar', que es su valor semántico básico. El verbo no selecciona exclusivamente AAEE [+ humanos], puesto que cualquier ser vivo capaz de autopropulsarse puede realizar ese tipo de movimiento. Este significado no representa ninguna novedad respecto al latín, lengua en la que este valor semántico era el primario del verbo AMBULĀRE, el étimo más probable de andar (vid. $\S$ 3.1.). Asimismo, se trata de un uso ya existente en romance en épocas anteriores, como se ha indicado en el epígrafe 3.2.

En lo que respecta al aspecto formal, el corpus muestra que la forma andar es la predominante en los textos del siglo XIII, a pesar de que también permanecen de manera residual las formas ambulare y amblar en tres textos:

16. Dono itaque eidem monasterio et vobis monasteria et villulas que sunt prope Aguilar de Campo, que Porquera et Berlanga de las Infantes vocantur, cum ecclesiis, collaciis, hereditatibus, terminis et omnibus pertinenciis eorum et directuris, ut ea habeatis irrevocabiliter et possideatis pacifice in eternum iure hereditario, statuens et precipiens quod sint de Infantatico, sicut antiquitus esse solebant et ambulent cum eo sicut andare solebant (CORDE, Anónimo, Fernando III devuelve al infantado de Covarrubias las iglesias y lugares de Porquera y Berlanga de las Infantas, 1223).

17. Et assi como cuenta la estoria andaua quanto la su bestia podie amblar ${ }^{8}$ (CORDE, Alfonso X, General Estoria. Segunda parte, c1275).

Uno de los valores que adquiría andar cuando el AE realizaba la acción de caminar a lomos de algún animal es el de 'cabalgar', fenómeno que se encuentra documentado ya en latín en su correspondiente étimo (REW, s. v. AMBǓLA$\mathrm{RE}$ ). Además, según el $D E C H$ (s. v. caballo), en el siglo XI ya existía el verbo cabalgar, cuyo étimo se corresponde con el latín vulgar CABALLICARE, de modo que se daba la circunstancia de que convivían dos unidades léxicas con usos semánticos similares.

18. \& mandol que subiesse el en un cauallo. \& que tomasse otro que leuasse de diestro \& que yrie con el. [...] \& andidieron fasta que uinieron al Rio a que dizen tigre (CORDE, Alfonso X, General Estoria. Cuarta parte, c1280).

\footnotetext{
${ }^{8}$ Nótese que en este ejemplo se combina el uso de dos formas del mismo verbo: andar y amblar.
} 


\subsection{2. 'Desplazarse'}

Cuando es usado con este significado, el verbo andar suele escoger como AE palabras que poseen el rasgo [- animado], como nave, navío o planeta, y que pertenecen al grupo de los sustantivos que designan <objetos físicos y lugares $>$. Este tipo de selección semántica no aparecía documentada entre los siglos VIII y XII, sino que únicamente el corpus aportaba ejemplos en los que este verbo poseía un AE [+ animado]. No obstante, su presencia en el siglo XIII no representa, a nuestro parecer, una innovación semántica, puesto que en latín ya se documentaban empleos similares de andar junto a AAEE [- animados] (Gaffiot, 1934: $s$. $v$. AMBULO). Por lo tanto, la falta de ocurrencias de este tipo entre los siglos VIII y XII debe atribuirse probablemente al escaso número de documentaciones de ese periodo que recoge el CORDE.

19. Esta planeta es mas gran que la luna e toma lunbre e claridad del sol e segud dize el sabio esta planeta anda cunple todo su curso en derredor en trezientos e treynta e vn dia (CORDE, Anónimo, Semejanza del mundo, c1223). 20. Quand' apuntó el sol, cató contra la mar, vío luzir las ondas e las naves andar (CORDE, Anónimo, Libro de Alexandre, 1240-1250).

Este valor semántico es el resultado de un proceso de metaforización mediante el cual una entidad [-humana] es concebida como tal, de manera que es posible atribuirle las mismas propiedades y capacidades que si lo fuera (vid. Lakoff y Johnson, 1986: 71-72). Este mecanismo de personificación permite referirse al movimiento de los astros de manera clara e intuitiva; de ahí que los tratados de astrología sean una de las tradiciones discursivas en las que más abunda este de uso de andar.

El movimiento de los planetas se caracteriza por no tener un origen ni una meta definidas, sino que sigue de manera continua una órbita alrededor de otro cuerpo celeste. Estas circunstancias favorecerían la elección del verbo andar, ya que se trata de un verbo que no delimita un desplazamiento y no incorpora un origen ni una meta implícitos (19).

En el caso de lexemas como nave o navío (20), actúa, además, un proceso de metonimización (Lakoff y Johnson, 1986: 73-78) debido a que designan medios de transporte, es decir, artefactos en los que pueden viajar las personas y a los que, por continuidad, se les atribuyen las mismas propiedades que a ellas.

\subsection{3. 'Recorrer un espacio físico'}

A pesar de que la gran mayoría de las ocurrencias del corpus están compuestas por usos intransitivos de andar, también las hay en las que este predi- 
cado selecciona un argumento interno ${ }^{9}$ con la función de complemento directo. Esta posición es ocupada normalmente por sustantivos que designan <objetos físicos y lugares>: África, calle, camino, carrera, cerco, cielo, ciudad, cuesta, insula, lugar, monte, mundo, partida, pieza, puerto, pueblo, reino, ribera, santuario, templo, término, tierra y villa. Para la posición de AE, andar selecciona sustantivos que designan <seres materiales e inmateriales>, como confesor, Danao, hijo, hombre, María, Olofernes, o bien nombres pertenecientes a la clase léxica de los <objetos físicos y lugares>, como luna, río o sol. Se trata de un uso de andar que el CORDE documenta por primera vez en el siglo XIII.

21. Los omnes andudieron toda la uilla por calles. \& por casas $(C O R D E$, Alfonso X, General Estoria. Cuarta parte, c1280).

22. Dize Tolomeo. que atura la question; quanto atura de andar el Sol todo el cielo una uegada (CORDE, Anónimo, Judizios de las estrellas, 1254-1260). 23. Et o tu rromano esta cobidçia que tu as de querer saber el fecho del njlo essa mesma oujeron los Reyes de egipto cuya tierra este rrio anda (CORDE, Alfonso X, General Estoria. Quinta parte, a1284).

La razón por la que andar admitía este tipo de construcciones se encuentra en sus características sintáctico-semánticas. La intransitividad es la propiedad que limita la selección semántica del predicado a un único argumento de tipo externo que, sintácticamente, realiza la función de sujeto (Mendikoetxea, 1999: 15781579). No obstante, el hecho de que andar posea esta propiedad no lo incapacita para seleccionar un complemento directo, sino que éste no forma parte de la estructura argumental del predicado, es decir, se trata de complementos que reiteran la información implícita en el contenido semántico del verbo (Campos, 1999: 1527).

\subsubsection{1. 'Moverse una pieza por las casillas de un tablero'}

Uno de los significados concretos del valor semántico general 'recorrer un espacio físico' es el de 'moverse por las casillas de un tablero'. No existe constancia en el CORDE de testimonios previos al siglo XIII de este uso específico ${ }^{10} \mathrm{y}$, de hecho, todos los casos pertenecen al Libro de ajedrez, dados y tablas.

Esta obra, una de las más importantes de la producción alfonsí y más peculiares en cuanto a sus características, está compuesta por cuatro tratados en los que se detalla la manera de jugar a diversos juegos de mesa de la época: el Libro

9 En adelante, AI.

${ }^{10} \mathrm{Si}$ bien no se tiene constancia de empleos de este tipo del verbo andar anteriores al siglo XIII, esta unidad no es la única que adquiere un significado de estas características ligado al juego de mesa del ajedrez. También se ha documentado que el verbo entrar se utilizaba en el sentido de 'atacar una pieza del oponente en el juego del ajedrez' en Paz (2013). 
de acedrex, el Libro de los dados, el Libro de las tablas y el Libro del grant açedrex, del alquerque e del tablero que se juega por astronomía. La presencia del verbo andar registrada en el CORDE pertenece al primero de ellos, un texto elaborado con la finalidad de explicar el funcionamiento del ajedrez a través de su semejanza con los movimientos tácticos y el desarrollo de la guerra (vid. Paz, 2013), como se desprende del texto de Gómez Redondo (1998: 828):

Todo ayuda a construir esta dimensión semántica: el alférez "tiene la seña de las señales del rey", $i d$., $29^{11}$; los alfiles equivalen a los "elefantes, que solíen los reyes levar en las batallas", 14, 2-3; de los caballos se recuerda que "los sus nombres derechos son cavalleros", id. 6-7; y los roques son "a semejança de las azes de los cavalleros", íd., 11. Y lo mismo ocurre con los principales movimientos, o lo que se llama "el andar de los juegos", 16, 3.

Tal y como se menciona en la cita anterior, a cada uno de los movimientos que intervienen en el ajedrez se le denomina andar. Así pues, dado que el objetivo dar a conocer este juego, es lógico que abunde este uso de andar para explicar las posibles jugadas $(24,25)$.

24. El peon puede seer fecho alfferza en .vj. uezes que ande las casas una a una \&; tornarse a su casa pues que fuere alfferzado en tantas uezes como la otra alfferza. andando todas las casas del tablero; que puede andar (CORDE, Alfonso X, Libro de ajedrez, dados y tablas, 1283).

25. Ell alferza anda a una casa en sosquino \& esto es por aguardar al Rey \& non se partir del. \& por encobrirle de los xaques \& de los mates quando ge los dieren (CORDE, Alfonso X, Libro de ajedrez, dados y tablas, 1283).

En este contexto, andar selecciona un AE que designa piezas del tablero (alferza, rey, reina, etc.), mientras que la posición de AI suele estar ocupada por la palabra casa, ya sea introducida o no por preposición. Este sustantivo hace referencia a cada uno de los escaques que componen el tablero, es decir, lo que actualmente se entiende como casilla. Así pues, se constata la relación entre esta voz actual y el mencionado uso de casa, que se explicaría a partir de un proceso de lexicalización de la palabra casa con el sufijo diminutivo -illa ${ }^{12}$. Por tanto, andar las casas equivale a 'moverse por las casillas del tablero de ajedrez'.

\footnotetext{
${ }^{11}$ Las citas empleadas por Gómez Redondo (1998: 828) pertenecen a Steiger (1941).

12 La reconstrucción del origen de la voz casilla con el significado "cada uno de los compartimentos en que quedan divididos los tableros de otros juegos' (DRAE, 2001: s. v. casilla) excede, obviamente, los límites de este artículo y requeriría un estudio en profundidad.
} 


\subsection{4. ' $I r '$}

Tradicionalmente, el verbo andar ha sido considerado como un verbo carente de direccionalidad. Sin embargo, se documentan usos de este predicado con el rasgo [+direccional] desde los orígenes del español (Paz, 2008: 21-22), así como en el propio étimo latino AMBULĀRE ( $R E W, s . v$. AMBŬLARE), si bien es cierto que aparecen de forma esporádica.

En esta situación, suele poseer un AE de la clase léxica <seres materiales e inmateriales>, como Gad, hijo o rey.

26. En las partes de Aquario. es açorero que ama seguir a omnes que fuyen. \& ama caçar. \& ama mucho andar. \& uenir. \& es de mucho mouimiento. faze cosas que nol tienen pro. en sus faziendas ni en sus uictos (CORDE, Anónimo, Judizios de las estrellas, 1254-1260).

27. Andad fijos andad. ca yo desamaparada so de uos. \& sola finco (CORDE, Alfonso X, General Estoria. Cuarta parte, c1280).

En el ejemplo 26 es posible interpretar que este es el uso del verbo por su coordinación con venir, lo que da a entender que existe una relación semántica entre ambos predicados. En cambio, en 27 el contexto tiene un mayor grado de ambigüedad, aunque resulta más coherente una lectura direccional incoativa en la que la mujer incita a los hijos a irse que a caminar. Además, este uso interjectivo ya se encontraba presente en AMBULĀRE, según los datos del DHLF (s. v. aller) y del $D E C H$ (s. v. andar), siendo especialmente común en el ámbito militar para estimular la ejecución de una acción.

\subsection{Usos figurados de andar}

En este grupo se incluyen todos aquellos significados de andar que no hacen referencia a movimientos en el espacio, sino a empleos figurados ${ }^{13}$, fruto de procesos de metaforización facilitados por sus características semánticas y aspectuales, especialmente la ‘indeterminación' (García Padrón, 1990: 247). Estos significados son: 'haber, existir', 'actuar dejándose llevar por alguien o algo o bajo su mandato', 'actuar en beneficio o en contra de algo o alguien', 'hacerse pasar o actuar en

${ }^{13}$ El uso de los verbos de movimiento con sentido figurado es una característica propia de este tipo de unidades desde los orígenes del romance hasta la actualidad que no se limita únicamente a andar, sino también a voces como ir, venir, llevar, traer, caer, meter, entrar, salir, llegar, tornar, pasar y volver, entre otros (Alonso, 1974; Coseriu, 1977; Crego, 1994, 2000, 2002; Galán, 1988; Garcés, 1992; Julià y Paz, 2012; Martín Zorraquino, 1993, 1998; Melis, 2006; Paz, 2009, 2013, en prensa a, en prensa b; Roca, 1954; Sánchez Jiménez, 2011; Sarrazin, 2011, Serradilla, 2011). 
calidad de alguien', 'transcurrir un periodo de tiempo', 'buscar, perseguir' y 'estar pendiente, vigilar'.

\subsection{1. 'Haber, existir'}

Existen múltiples casos en los que andar parece ser utilizado con un significado próximo a 'haber, existir', cuya aparición debió estar relacionada con la naturaleza no delimitada de andar (Morimoto, 2001: 183) y sus rasgos semánticos. A la luz del corpus, este uso se documenta por primera vez en el siglo XIII.

El sustantivo que ocupa la posición de AE no pertenece únicamente a la clase léxica <seres materiales e inmateriales>, como caballero o ganado, sino andar que puede seleccionar también palabras de las categorías <objetos físicos y lugares>, como cartas y mensajerías, <entidades abstractas>, como avenencia, desacuerdo, desamor, lealtad o espíritu, y <conflictos>, como batalla o querella.

28. E non se fallo ende otro que tan buen cauallero commo el andouiesse njn que tanto pelease (CORDE, Anónimo, Castigos, BNM ms. 6559, 1293).

29. Credieron estos dichos e estas prophecías, andidieron las cartas e las messagerías, fueron con estas nuevas ante de pocos días aplegados los pueblos e las cavallerías (CORDE, Gonzalo de Berceo, Vida de San Millán de la Cogolla, c1230).

30. Porque entre los que venden e compran siempre á de andar palabra medianera (CORDE, Alfonso X, General Estoria. Primera parte, c1275).

31. Acordaron luego ellos todos en uno. \& non conssentieron a los mayores. que desacuerdo nin desamor andidiesse entrellos estonces poco nin mucho (CORDE, Alfonso X, General Estoria. Cuarta parte, c1280).

32. Primeramente tenemos por bien por que la nuestra hermandad sea mas conplida de poner en mano de tres amigos de abenençia todas quantas querellas andan entre vos e nos (CORDE, Anónimo, Carta de hermandad, 1293).

Aunque no es lo más habitual, andar puede presentar un AI de la clase $<$ seres materiales e inmateriales $>$, constituido a partir de entre y la coordinación de dos sustantivos, o <partes del cuerpo $>$, precedido por en o entre.

33. Et esta enfermedat nasze de mucha sangre podrida \& de humor malo que anda entre el cuero y la carne (CORDE, Anónimo, Libro de los caballos, c1275).

34. Et pues que tal abenencia. \& paç. andido entre madre. \& fijo. [...] non finco de yr el muy derrezio contra los aragoneses (CORDE, Alfonso X, Estoria de España, II, 1270-1284). 


\subsection{2. 'Actuar dejándose llevar por alguien o algo o bajo su mandato'}

Este uso de andar se encuentra documentado en ejemplos previos al siglo XIII (Paz, 2008: 19-20) y se explica a partir de un proceso de metaforización. La mayoría de ocurrencias corresponden a textos notariales, fueros o biblias romanceadas, por lo que la tradición discursiva parece condicionar el uso de esta unidad léxica.

Cuando andar adopta este significado el AE seleccionado pertenece, en todos los casos que aparecen en el corpus, a la clase léxica <seres materiales e inmateriales>, como animalia, hijo, Dios, ganado, monja, Moisén, pastor, Philomena, Thereo, todos, traidor o varón.

El sustantivo seleccionado por andar para ocupar la posición de AI puede designar, por su parte, una amplia variedad de conceptos. Cuando selecciona palabras pertenecientes a la clase <seres materiales e inmateriales $>$ (caudillo, Dios, hombre, pastor), éstas van precedidas por las preposiciones a, según y tras. Si la preposición es sin, el significado adquiere el valor negativo, es decir, 'actuar sin dejarse llevar por nada, nadie ni bajo su mandato'.

35. Et ganado que andare a pastor et danno fizier en era de dia non pectet, et el que non andudier con pastor, pectet ut supra dictum est (CORDE, Anónimo, Fuero de Cáceres, c1234-1275).

36. E yo, hermanos, no uos pud fablar assi cuemo a espiritales, mas assi cuemo a carnales, que sodes ninnos en Ihesu Christo.[...] Pues ¿non sodes carnales, auiendo entre uos enuidia e contienda, e andades segund ombres? (CORDE, Anónimo, El Nuevo Testamento según el manuscrito escurialense I.j.6., a1260)

37. E levantar se á este pueblo e fornigará andando tras los dioses agenos en la tierra a que van, e allí me desamparará e quebrantará este pueblo la mi postura que yo pus con él e tornar la á a nada (CORDE, Alfonso X, General Estoria. Primera parte, c1275).

38. Del ganado que anda sin pastor e façe danno (CORDE, Anónimo, Fuero de Alarcón, 1300).

Andar también selecciona como AI sustantivos que designan <objetos físicos y lugares $>$, como carne, carrera, término o vía. A diferencia de lo que ocurría con la clase léxica <seres materiales e inmateriales>, en esta ocasión estos sustantivos constituyen el término de las preposiciones en y por, así como de la locución prepositiva fuera de.

39. \& tu andest enlas carreras de ieroboam \& fezist peccar al mi pueblo israel por fazer ami ensannar por los peccados dellos (CORDE, Anónimo, Biblia. Escorial I.j.8., a1300).

40. Conviene al ome que muestre cada día a sí mesmo todas sus obras, e que pugne en saber que dizen d'él sus vezinos, e los que andan con él, e han de 
dar e de tomar con él, e qué cosa es, con que lo alaban e con lo que le denuestan. E quando andudiere por esta carrera, non se esconderán d'él ninguna de sus tachas (CORDE, Anónimo, Bocados de oro, a1250).

41. Empero los uezinos deuen auer manera que cerqua tales cosas el I al otro non fagan daynno ni nozimiento, goardando a ssí mismos de daynno coanto pueden, a la quoal cosa encara cada I deue ser constreynnido de goardar, si cerqua estas cosas [contesce] que alguno quiera fazer algo malitiosament et andar fuera de carrera (CORDE, Anónimo, Vidal Mayor, c1250).

Es muy frecuente que la posición del locativo la ocupen sustantivos que designan <entidades abstractas>, siendo gran parte de ellas sentimientos (amor, codicia, cordura, deseo, engaño, folía, locura, maldad, pena, temor, traición, vanagloria, vanidad, voluntad), aunque no de forma exclusiva (también aparecen bien, costumbre, espíritu, forma, mal, mentira, muerte, pereza, razón, resemejanza, semejanza y verdad). Las preposiciones por las que pueden ir introducidos estos sustantivos son $a$, en, por, según y tras.

42. Dina, fija de Jacob e de Lía, salió esse día, e iva sola a la cibdad por veer las mugeres d'allí e d'aquella tierra, e otrossí, segund diz Josefo, por comprar de las abtezas d'ellas con que se guisasse pora andar a costumbre d'aquella tierra ó veyé que avrié de morar (CORDE, Anónimo, General Estoria. Primera parte, c1275).

43. $\mathrm{D}[\mathrm{e}]$ las $\operatorname{ar}[\mathrm{m}]$ as non ha cura \& otrosi de lidiar, ca mas val seso \& mesura que sienpre andar en locura, commo el tu cauallero que ha vidas de garçon (CORDE, Anónimo, Elena y María (Disputa del clérigo y el caballero), c1280).

44. Los que de Christo son, su carne crucifigaron con uicios e con cobdicias. [Esto es, mataron su carne penando la, auiendo la cobdicia de los uicios e no los querer. Diz el testo:] Si por Espirito uiuimos, por Espirito andemos (CORDE, Anónimo, El Nuevo Testamento según el manuscrito escurialense I.j.6, a1260).

45. Ca si a to hermano contrallares por la uianda, ya no andas segund amor. Non pierdas tu por el comer aquel por que Christo murio (CORDE, Anónimo, El Nuevo Testamento según el manuscrito escurialense I.j.6, a1260).

46. Que fallaron de maldat los uuestros padres en mi que se alongaron de mi. \& andudieron tras uanidat \& son fechos uanos (CORDE, Alfonso X, General Estoria. Cuarta parte, c1280).

Otra clase léxica frecuentemente seleccionada como AI es la de <autoridad>. Este conjunto lo integran palabras como consejo, derecho, fuero, ley, mandado, mandamiento, orden, poder y regla, que constituyen el término de las preposiciones $a$, en, por y según, así como de la locución prepositiva fuera de y la preposición sin cuando el significado es negativo.

47. Enpero, todos aquestos iuez, alcalde, notario et clerigo pueden sobreleuar aaquellos que su pan comieren, enpero iurando primera mente que su pan co- 
men, et a sus mandamientos andan: ante del sacramento non sean reçebidos (CORDE, Anónimo, Fuero de Zorita, 1218-c1250).

48. Non se alimpiaron fastal dia de oy. nin temieron nin andaron en la ley del sennor. nin en los mios mandados que di yo a uos \& a uuestros padres (CORDE, Alfonso X, General Estoria. Cuarta parte, c1280).

49. Et aquellos que ge lo consejaron o que 1 aiudaron, si non eran omnes que andudiessen por su mandado \& eran omnes libres, cada uno peche XV morauedís a aquel que fizioron el tuerto, \& reciba demás cada uno $\mathrm{C}$ azotes (CORDE, Anónimo, Fuero Juzgo, c1250-1260).

50. E esto non fue assí después de la su passión, ca los que en él crovieron después d'ella e andudieron segund los mandados de la su ley e sin pecado mortal morieron non fueron a infierno (CORDE, Alfonso X, General Estoria. Primera parte, c1275).

51. Otrossí non pueda testimoniar contra otro que aya parte en la demanda, nin nenguno que non aya .XVI. annos complidos, [...] nin omne que ande fuera dorden sin liçencia de su mayor (CORDE, Alfonso X, Fuero Real, 12511255).

52. Dezimos que pueden sseer dessechados de testimonjo. ley. vij. quales perssonas otrossi non pueden testiguar otros [...] njn varon njn mugier que ssalle de orden \& andan ssin liçençia de ssu mayoral (CORDE, Anónimo, Espéculo de Alfonso X, a1260).

Por último, andar también puede tener este significado cuando selecciona una palabra que designa <partes del cuerpo> precedida por la preposición según o sin, en este último caso si se trata de un valor negativo, como se ha comentado con anterioridad.

53. E por que non podie seer por la ley, en que enfermaua ombre por la carne, enuio Dios el so Fiio en semeiança de carne de pecado, [...] por que la derechuria de la ley fuesse complida en nos, que no andamos segund la carne, mas segund el espirito (CORDE, Anónimo, El Nuevo Testamento según el manuscrito escurialense I.j.6, a1260).

54. Demientre que don Jósep esto ál recabdava, yo lazdrava mesquina, de plorar non cesava; reptava al mi fijo porque non me fablava, yo bien me entendía que sin seso andava (CORDE, Gonzalo de Berceo, El duelo de la Virgen, p1236-1246).

Una de las propuestas para explicar de qué manera un verbo de movimiento como andar puede llegar a denotar un significado figurado de este tipo es la hipótesis localista de Fillmore (1968), Lyons (1971, 1975) y Anderson (1971). Según este planteamiento, las experiencias espaciales son fundamentales para conceptualizar el mundo que nos rodea y constituyen primitivos lingüísticos. Andar es un verbo que denota una manera de moverse, por lo tanto, si se proyecta cognitivamente este rasgo relativo al movimiento - dominio origen en el comportamiento de las personas — dominio meta-, la experiencia espacial sirve a los hablantes para conceptualizar algo tan abstracto como la manera de actuar. 


\subsection{3. 'Actuar en beneficio o en contra de algo o alguien'}

Este uso de andar se diferencia del descrito en $\S$ 4.2.2. en que no presenta un componente autoritario que rija el comportamiento según unas órdenes, sino que la actuación del ae busca simplemente un beneficio, sin que necesariamente sea por mandato de alguien. Se trata, además, de un valor semántico ya existente en documentaciones previas al siglo XIII.

La posición de AE la ocupan sustantivos que designan <seres materiales e inmateriales>, mientras que el AI suele estar ocupado por un sustantivo de la clase <entidades abstractas>, (mal, placer, pro, salud, servicio o voluntad). Las preposiciones por las que estas palabras van introducidas son $a$, en y por.

55. Et yo por esta Razon enbio uos a anbros que es omne que andara a vuestro plazer \& que es uuestro amigo \& vuestro pariente (CORDE, Alfonso X, Estoria de España, II, 1270-1284).

56. Falso es el omne que te yo agora dire lo primero por mentir asu señor [...] \& andar ensu mal \& ensu daño \& ensu deseredamiento (CORDE, Anónimo, Castigos BNM ms.6559, 1293).

57. Si por mi salut andas, o quieres que te crea, descúbrite quí eres por ond certero sea, ca si rafez me muevo témome de pelea, sé que los mis costados sovarán la correa (CORDE, Gonzalo de Berceo, Vida de Santo Domingo de Silos, c1236).

\subsection{4. 'Hacerse pasar o actuar en calidad de alguien'}

Cuando andar adquiere este significado $^{14}$ selecciona como AI sustantivos que designan <seres materiales e inmateriales> (adivino, aliñador, amigo, doncel, jinete, mayoral, privado, señor, rey, vencedor, virgen, etc.) precedidos por las preposiciones por y según, o bien palabras de la clase léxica <objetos físicos y lugares $>$, como lugar, introducidos por en.

El AE puede ser un sustantivo perteneciente a dos categorías: <seres materiales e inmateriales $>$, como diablo, hombre, mujer o varón, o, con menor frecuencia, al grupo <objetos físicos y lugares>, como sol.

58. Otrossi mando, en razon de los moços coronados et de los otros que andan segund clerigos e son casados, que pechen assi commo solien pechar en tienpo del rey don Alfonso, mio visavuelo (CORDE, Anónimo, Carta de Ordenanzas, 1252).

59. La gent de los judíos, en ora mala nados, repoyaron a Christo por sus malos pecados; recibiéronlo moros, fueron bienaventurados, éssos andan por

\footnotetext{
${ }^{14}$ El significado 'hacerse pasar o actuar en calidad de alguien' es un empleo figurado que andar comparte con otros verbos de movimiento, como entrar (Paz, 2013, en prensa b) y salir (Paz, en prensa a).
} 
fijos los otros por añados (CORDE, Gonzalo de Berceo, Del sacrificio de la misa, p1228-1246).

60. Don Martín Fernández, obispo que fue de León, lle mostrara una sentencia e vna enquisa [...], la qual pesquisa este Ferrán Fernández feziera por su mandado e de la reyna donna Yolante su moger, que andaua entonçe per la tierra en lugar del rey (CORDE, Anónimo, Mandato real, 1295).

61. Et el tiempo en que se asconde. \& los dias en que es encubierta; son los dias en que anda el sol de su logar quando se ella asconde fasta que llega a su logar quando ella apparece (CORDE, Maestro Bernaldo, Libro de la açafeha, 1277).

Una vez más, se trata de un valor semántico fruto de una extensión metafórica, que, además, se documenta por primera vez en el CORDE en el siglo XIII. La condición de hijo o de hombre libre se conceptualiza como si se tratase de la senda a través de la cual o en la que se produce la acción de caminar; de ahí, que la estructura que denota este significado sea andar por o andar en. En cuanto a según, es una preposición que establece un punto de referencia, a partir del cual se produciría el movimiento. Esta es la base semántica que permite extrapolar este significado al comportamiento humano mediante un proceso de metaforización.

\subsection{5. 'Transcurrir un periodo de tiempo'}

El empleo del verbo andar para expresar conceptos o ideas relacionadas con el tiempo se encuentra documentado antes del siglo XIII (Paz, 2008: 20-21). Este significado es fruto del salto, en términos cognitivos, del dominio locativo al dominio temporal, un fenómeno que se generaliza en el siglo XIII respecto a etapas anteriores ${ }^{15}$, tal y como se ha podido constatar en el corpus.

Tanto el sustantivo seleccionado como AE como el que ocupa la posición de AI son palabras de la clase léxica <periodos temporales>, como, año, día, era y mes. La mayoría de ocasiones aparecen junto a las preposiciones de, en y por.

La estructura días por andar o años por andar (vid. Paz, 2010) es extremadamente frecuente en cartas y tradiciones discursivas vinculadas a los documentos notariales en los que la fecha del momento en que fueron escritos tenía una especial relevancia.

62. Nos damos tregua por nos e por todos nuestro vanallos e de todas las tierras de nuestro sensorio a todos los luegares [...] e a los habitantes en aquellos a buena fe e senes engañillo de oy dia viernes veynt e seys dias andados del mes de julio present entro quel dicho don Johan sea de edat de vint aynos (CORDE, Anónimo, Capitulación de Elche, 1296).

15 Este mismo fenómeno se ha documentado en el caso del verbo entrar, que en esta época era utilizado también para la expresión del paso del tiempo (Paz, 2013, en prensa b). 
63. \& otrosí [mandamos guardar] en el tienpo que cogen las miesses, quinze días por andar de agosto \& quinze días andados de setembrio (CORDE, Anónimo, Fuero Juzgo, c1250-1260).

El tipo de construcciones mencionadas se corresponde con el sistema cronológico de la Alta Edad Media, que distinguía entre los días andados y los días por andar. Este método de datación, denominado consuetudo bononiensis o sistema de los días andados y por andar, fue heredado de la Roma antigua y se mantuvo durante los primeros siglos del medievo, si bien se simplificó su funcionamiento. Tal sistema concebía los meses en dos partes: cuando se quería hacer referencia a una fecha entre el día 1 y el 15 (en función del número total de días de ese mes, la primera mitad podía finalizar un día antes o después), se utilizaba la fórmula días andados, mientras que si la fecha en cuestión se encontraba entre el 16 y último día del mes, se empleaba días por andar (Cárcel, 1994: 139-140; Paz, 2010: 370-371).

El verbo andar usado en el dominio temporal implica la intervención de un proceso metafórico mediante el cual el tiempo es concebido como un camino. La diferencia entre este par de construcciones estriba en la perspectiva que adopte el hablante (Paz, 2010: 372-375; Melis, 2006: 884-889), es decir, si se tiene en cuenta el origen del trayecto y se hace hincapié en el camino recorrido (días andados) o si, por el contrario, se toma como referencia la meta y se indica el camino que aún queda por recorrer (días por andar). Por ese motivo, este uso no se limitaba únicamente a construcciones en las que el marco temporal de referencia era el mes, sino que este también podía ser un reinado o incluso un pleito, como en los ejemplos que siguen.

64. Aquellos cuatro reyes faraones que regnaron en Egipto en aquel tiempo que dezimos fueron éstos por sus nombres segund la fabla egipciana: el primero Mefres, en cuyo regnado finó Josep tres años por andar d'él (CORDE, Alfonso X, General Estoria. Primera parte, c1275).

65. Et si aquel en cuyo asentaren por mengua de respuesta ante de los tres meses viniere responder e fuere tornado en aquello en que assentaron al otro $\mathrm{e}$, andando el pleito, por su mengua, el alcalde assentare al otro otra uez, este assentamiento segundo sea desta guisa: que aquel que fuere assentado en ello sea dello tenedor fata que el pleito sea acabado (CORDE, Anónimo, Establecimiento de normas de juicios, 1254).

En 64 se hace referencia al tiempo que faltaba para que finalizara el gobierno de Mefres y, por lo tanto, se toma como referencia la meta del camino, idea que incorpora implícitamente la palabra reinado, dado que tiene un inicio y un final. Así pues, andar incrementó su presencia en sus ámbitos de uso temporales, ya que pasó de utilizarse para denotar una fecha del calendario a usarse para poner de manifiesto cualquier punto cronológico concreto en un marco referencial temporal que comportara un inicio y un final. 
Otra de las novedades del siglo XIII, según el CORDE, es la aparición de combinaciones como andar el año de, andar el año en y andar la era de. Habitualmente se encuentran en relatos, textos notariales, crónicas y documentos historiográficos y andar aparece conjugado en pretérito imperfecto. El AE se encuentra pospuesto al verbo y es un sustantivo de tipo temporal [-animado], lo cual es el resultado de un proceso de personificación, puesto que año y era son las voces encargadas de "ejecutar el movimiento". El sintagma que aparece tras la preposición equivale al lugar físico por el que se produce el desplazamiento.

66. Et el tiempo que andaua la era en Mil \& trescientos \& quinze annos. \& auia .xxv. annos que el regnaua; fizolo componer \& enderezar (CORDE, Alfonso X, Libro del Alcora, 1277).

67. Et yo don Miguel sobredicho obligome por mi et por todos mios bienes de vos dar deste primero dia de Marcio que vien ena era desta carta a un anno treinta morabetinos, et deste dia mismo a dos annos que andara la era de mille et $C C C^{a}$ et catorze annos, los quarenta morabetinos que fincan (CORDE, Anónimo, Carta de compra, 1274).

68. Fue presa la villa de vbeda segunt cuenta la estoria enla era de mill $\&$ doscientos \& setenta \& tres annos X andaua el anno dela encarnación del senor en mill \& doscientos \& treynta \& tres (CORDE, Alfonso X, Estoria de España, II, 1270-1284).

69. Et fue este reynado andando el.lxvio. anno del iudgado de aoth (CORDE, Alfonso X, General Estoria. Segunda parte, c1275).

Una construcción semejante, aunque semánticamente distinta de las anteriores, es andar en el año. Esta estructura focaliza la figura del AE, que en este caso es siempre un sustantivo de la clase léxica <seres materiales e inmateriales> y es quien realiza la acción del desplazamiento a través del periodo cronológico. Éste, a su vez, equivale a lo que en términos locativos sería la trayectoria o "camino".

70. Andados aquellos primeros diziocho annos de tiberio cesar. \& fue esto ueynte tres annos ante que Nero regnasse. porque dezimos que tantos annos como estos se deue començar esta cuenta mas a arriba del anno en que agora andamos del rey artaxerxes (CORDE, Alfonso X, General Estoria. Cuarta parte, c1280).

\subsection{6. 'Buscar, perseguir'}

En la mayoría de ocasiones, el $\mathrm{AE}$ es un sustantivo que designa <seres materiales e inmateriales $>$, como compaña, Diocles, pueblo o toro. Como AI, andar selecciona también palabras de la mencionada clase léxica (asno, codicioso, ganado, rey, vaca, venado), voces que designan <entidades abstractas> (alma, 
justicia) $\mathrm{u}<$ objetos físicos y lugares $>$ (agua). Las preposiciones que introducen estas palabras son $a$, por y tras.

71. Orat otrossi por nos, que Dios nos abra puerta de plaura pora fablar el fecho de Christo [...] Con saber andat a los que son fuera, redimiento el tiempo (CORDE, Anónimo, El Nuevo Testamento según el manuscrito escurialense I.j.6, a1260).

72. En esta mansion faras ymagenes pora meydrar los moços \& pora mostrar les los menesteres \& por andar saluos los que andan camino. \& que tornen ayna \& por andar saluos los que andan por agua. \& por meydrar las fraguas (CORDE, Alfonso X, Picatrix, 1256).

73. Si andudieres tras iusticia alcançarla as (CORDE, Alfonso X, General Estoria. Cuarta parte, c1280).

La preposición $a$ hace referencia a la meta del movimiento, lo que metafóricamente puede identificarse como dirigirse a alguien que se encuentra en el destino del desplazamiento. Por lo que se desprende de los datos del corpus, $a$ únicamente aparece junto a sintagmas [+ humanos]. El uso de la preposición por mantiene cierto paralelismo con el que presenta en la construcción actual ir por 'traer' (DRAE, s. v. por). En el caso que nos ocupa, su presencia junto al verbo andar aporta un matiz relacionado con la obtención de algo. Por su parte, tras es una preposición que permite designar la situación pospuesta de un elemento respecto a otro que se encuentra delante o en una posición más prominente, ya sea espacial o temporal. A juzgar por los datos del CORDE, se trata de una innovación semántica propia del siglo XIII.

\subsection{7. 'Estar pendiente, vigilar'}

Este valor semántico se manifiesta a través de la construcción <seres materiales e inmateriales $>+$ andar sobre $+<$ seres materiales e inmateriales $>$.

74. E departen que por ventura que fue esto por señal que assí como pujara ell agua e creciera tanto que corriera sobre la tierra que assí crescrién ellos e pujarién e andarién sobre sus enemigos de guisa que los quebranrién e los destroirién (CORDE, Alfonso X, General Estoria. Primera parte, c1275).

75. E dio a Beseleel e a Ooliab por mayorales que andudiessen sobre los otros maestros e los enseñassen (CORDE, Alfonso X, General Estoria. Primera parte, c1275).

El proceso metafórico presente en estas construcciones está relacionado con la posición espacial de superioridad que implica la preposición sobre y que, por lo tanto, permite dominar, aunque sea de forma visual (vigilando), todo lo que se extiende ante la vista. De nuevo, es un significado no documentado antes del siglo XIII en el CORDE. 


\subsection{Usos de andar como verbo gramaticalizado o en proceso de gramaticali- zación}

Andar no siempre muestra un uso como verbo pleno, sino que también era frecuente que fuera utilizado como auxiliar a partir de un proceso de gramaticalización. Como señala, García Padrón (1990: 242), esto ocurre en determinados contornos lingüísticos y extralingüísticos "en los que se realza más la no determinación del sujeto al desplazarse que el hecho físico en sí del proceso". En tales casos, este predicado no se empleaba como verbo de movimiento ni con un valor figurado, sino que aparece despojado de una parte o de la totalidad de su carga semántica a raíz de un progresivo desgaste semántico. En palabras de Melis (2006: 884), en su uso gramaticalizado representa "todo lo que tiene la vida de variable, iterativo o episódico". Los significados que adoptaba andar son los siguientes: 'encontrarse realizando una acción', 'encontrarse en un determinado estado' — ambos documentados en siglos anteriores- y 'participar o estar ocupado en algo' —un empleo de andar sin presencia en el corpus hasta el siglo XIII.

\subsection{1. 'Encontrarse realizando una acción'}

Normalmente andar selecciona como AE sustantivos que designan <seres materiales e inmateriales $>$ (ganado, ladrón, etc.), mientras que la posición del AI suelen ocuparla predicados que designan acciones diversas, como buscar, dar voces, demandar, hurtar, lidiar, mendigar, pedir, pescar, robar, saltar, sembrar, etc.

76. Et por ende Ssant Iohán Babtista andaua dando bozes por los desiertos para caçar los peccados, assí commo el león anda buscando la presa que caçe (CORDE, Alfonso X, Setenario, c1252-1270).

77. E si uieren que [las aves menores] ${ }^{16}$ se alegran e andan mucho saltando por las perchas, métanles uaras de callos e sean enbueltas en lana, e que sean enuestidas de suso de panno cosido (CORDE, Abraham de Toledo, Moamín, 1250).

En estos casos, andar actúa como un verbo auxiliar, ya que no es utilizado con su valor semántico básico de movimiento ${ }^{17}$. Sin embargo, conserva rasgos

\footnotetext{
${ }^{16}$ Los corchetes son nuestros.

17 Roca (1954) constituye una referencia fundamental sobre este tema debido al tratamiento monográfico que realiza del empleo auxiliar y copulativo de andar, tanto en la actualidad como a lo largo de la historia del español. Asimismo, sobre este aspecto destacan las investigaciones de Alonso (1974), Coseriu (1977), Green (1982), Kock (1975), Matthies (1933), Meier (1933), Melis (2006), Pottier (1961), Schmeliĉek (1930), Spaulding (1925-1928) e Yllera (1980).
} 
aspectuales originales como el de 'movimiento reiterado o indeterminado' (vid. Garcés, 1992; Roca, 1954; Alonso, 1974; Sarrazin, 2011), como puede comprobarse en 76 y 77 . Esto hace que aparentemente se comporte como un sinónimo de estar. Sin embargo, andar no posee el valor perfectivo de ese verbo, por lo que únicamente puede utilizarse con connotaciones reiterativas y no resultativas (Roca, 1954: 174).

Muy posiblemente las características semánticas y aspectuales de andar hayan facilitado este uso gramaticalizado, de la misma forma que influiría el hecho de que se tratara de un verbo básico en la lengua y de origen patrimonial.

\subsection{2. 'Encontrarse en un determinado estado'}

Este significado se produce generalmente cuando el verbo selecciona AAII que designan < faltas $>$, como erranza, error, pecado, radio, yerro, y <estados físicos o psicológicos $>^{18}$, tales como alegre, asegurado, cansado, conturbado, descalzo, enloquecido, embargado, fetillado, lazrado, libre, lozano, malo, pesado, triste, vestido, etc.

En el primer caso, el AI va precedido por la preposición en, mientras que, cuando andar selecciona una palabra de la clase léxica <estado físico o psicológico $>$, no media entre ellos ninguna preposición. Como AE, en cambio, lo más habitual es que aparezcan sustantivos que designen <seres materiales e inmateriales> (caballero, caudillo, compañero, cristiano, ganado, griego, hermana, hombre, león, madre, obispo, padre, pueblo, etc.), aunque también se documenta algún caso esporádico de <partes del cuerpo $>$.

Se trata de un uso extremadamente frecuente en todo el corpus, coincidiendo así con los autores que afirman que es precisamente en el siglo XIII cuando se consolida (Yllera, 1980: 299; Garcés, 1992: 439), si bien existen documentaciones previas a esta época en el CORDE. Los rasgos aspectuales de andar facilitaban que pudiera utilizarse con un valor con ciertas similitudes al de estar, generándose un proceso de gramaticalización en el que el significado físico de andar se veía reducido a la idea de "movimiento en el tiempo" (Yllera, 1980: 82). Sin embargo, su uso se diferencia del de estar por la connotación de acción acabada y estado resultante que éste posee y de la que carece andar (Garcés, 1992: 439).

78. Tu eres traydor a dios \& a mi. ca feziste matar todos los moros que tenien comigo. [...] \& feziste a muchos perder conseio \& andar pobres \& mesquinos (CORDE, Alfonso X, Estoria de España, II, 1270-1284).

${ }^{18}$ Tal y como apunta Yllera (1980: 299), la gran mayoría de palabras que componen esta clase léxica en el corpus designan un estado físico o psicológico negativo transitorio. 
79. Prendiéla a menudo la bestia percodida, andava en radío como cosa tollida, non trobavan consejo por ond fuese guaridda, plazrié a sus parientes de veerla transida (CORDE, Gonzalo de Berceo, Vida de Santo Domingo de Silos, c1236).

Es importante notar que pueden aparecer sintagmas prepositivos intercalados entre andar y el adjetivo o participio, de la misma manera que el AE puede aparecer pospuesto al verbo. Algunos de los complementos pueden ser de tipo cualitativo, con el fin de matizar el valor semántico del sustantivo.

80. Las bodas fueron fechas ricas e abondadas, andavan las carreras de conducho pobladas (CORDE, Anónimo, Libro de Alexandre, 1240-1250).

81. Desque murió la fija, sancta emparedada, andava la su madre por ella fetillada (CORDE, Gonzalo de Berceo, Poema de Santa Oria, c1252-1257).

82. El pueblo con el ninyo, que Dios les auié dado, andaua mucho alegre \& mucho asegurado (CORDE, Anónimo, Libro de Apolonio, c1240).

Además, es frecuente encontrar AAII formados por adjetivos coordinados:

83. Fueron todos los pueblos durament' espantados, como si fuessen ciertos de seer astragados; andavan los mesquinos tristes e desarrados, plorando de los ojos, reptando sus pecados (CORDE, Gonzalo de Berceo, Vida de San Millán de la Cogolla, c1230).

84. De toda tu fazienda te veyemos camiado, abés te connoscemos, tanto eres demudado; alegrarte non puedes, andas triste \& pesado (CORDE, Anónimo, Libro de Apolonio, c1240).

El AI puede encontrarse antepuesto al verbo, tal y como se muestra en 85 y 86 :

85. Quando vio la Natura al señor pesava, ovo grant alegría, maguer triste andava (CORDE, Anónimo, Libro de Alexandre, 1240-1250).

86. Sse entiende otrosí que los doze apóstoles que alunbraron el mundo, ffaziendo a los omnes connosçer a Dios uerdadero por ley e dexar las erranças en que andauan de las otras ssectas (CORDE, Alfonso X, Setenario, c12521270).

\subsection{3. 'Participar o estar ocupado en algo'}

El AE suele ser un sustantivo de la clase léxica <seres materiales e inmateriales>, mientras que el AI presenta una mayor variación. Esta posición puede ser ocupada por verbos en infinitivo precedidos por las preposiciones en y por, como andar en hacer bien, andar en hacer malas obras, andar en poner fecho, andar en prender, andar por buscar, andar por confundir, andar por matar, andar por meter paz, andar por recibir, andar por vengar, etc. 
87. ¡Que buena es la muerte pora aquel que anda en fazer bien a su alma pora quando fuere al otro sieglo! (CORDE, Anónimo, Libro de los buenos proverbios que dijeron los filósofos y sabios antiguos, c1250).

88. Onbres de Antioco me andan por matar, preso seré traýdo si me pueden fallar (CORDE, Anónimo, Libro de Apolonio, c1240).

Asimismo, este verbo puede seleccionar sustantivos de las clases léxicas <conflicto $>$ (batalla, conquista, contienda, demanda, guerra, lid, pleito), <objetos físicos y lugares $>$ (arma), <seres materiales e inmateriales> (ganado, hueste) o $<$ entidades abstractas> (hecho, muerte, obra). En estos casos, los sustantivos constituyen el término de las preposiciones $a$ y en.

89. E otrossí sobre razón que el bispo e el cabillo de León andando en pleyto conuusco per ante mí en razón de las aldeas sobredichas, e el pleyto seyendo entrado por respuesta, dizen que [...] detouieron en Mansiella Domingo Pérez (CORDE, Anónimo, Confirmación de exención de impuestos, 1270).

90. Et andudjmos nos en armas con peligro mayor de todo en todo que el mjedo non podiera seer (CORDE, Alfonso X, General Estoria. Quinta parte, a1284).

91. Qui furtare mastin que hande en el guanado \& traya guarranguas deue por calonia .lx. sueldos (CORDE, Anónimo, Fuero General de Navarra, 1250-1300).

92. Nos deuán dichos uendedores esta carta desta nuestra véndeda, que a uos do Yuanes, clérigo sobredicho, acomendemos escriuir, rouramos e confirmamos e esta senal en da mandemos fazer. Yuan Nieto, clérigo del coro, conf. Don Bortholomé de las Casas de Carrizo, conf. Don Abril, carpentero, [...] Johán Benéytez, que anda a la obra, conf. Iohán Martínez de los Palacios (CORDE, Anónimo, Documento de venta, 1261).

No resulta extraño que varios de estos vocablos pertenezcan al campo semántico militar, puesto que ya en latín el verbo AMBULĀRE estaba relacionado con este ámbito (DECH, s. v. andar).

\section{CONCLUSIONES}

Tras todo lo expuesto anteriormente, pueden extraerse diferentes conclusiones acerca de la caracterización del verbo andar en el siglo XIII, así como de sus contextos de uso.

Se ha demostrado que es posible realizar una caracterización de un predicado verbal a partir del análisis de sus restricciones semánticas sobre la selección argumental. La identificación de las clases léxicas ha permitido determinar los diferentes usos de andar en el periodo estudiado, así como establecer una clasificación de sus valores semánticos en función de su empleo figurado, gramaticalizado o como verbo de movimiento con significado físico. 
Los empleos rectos de andar se caracterizan por seleccionar AAEE de las clases léxicas <seres materiales e inmateriales> y <objetos físicos y lugares $>$, mientras que como AI únicamente selecciona sustantivos que designan <objetos físicos y lugares $>$. En contraste, destaca la amplia variedad de categorías léxicas que selecciona el predicado en los usos figurados. Los AAEE más habituales son, con diferencia, las palabras pertenecientes al grupo <seres materiales e inmateriales $>$, además de las palabras que denotan <objetos físicos y lugares $>$, <entidades abstractas $>$, <conflictos $>$ y $<$ periodos temporales $>$. Como AI, destacan nuevamente las voces que designan $<$ seres materiales e inmateriales $>$, seguidas de las que pertenecen a la clase $<$ partes del cuerpo $>$ y $<$ entidades abstractas $>$, y las no tan frecuentes <objetos físicos y lugares $>$, <autoridad $>$ y $<$ periodos temporales $>$. Finalmente, los usos gramaticalizados de andar se caracterizan por seleccionar siempre como AE unidades que designan <seres materiales e inmateriales $>$, mientras que la posición de AI se encuentra ocupada por una gran variedad de categorías posibles: <faltas $>$, <estados físicos o psicológicos $>$, <conflictos $>$, $<$ objetos físicos y lugares $>$, <seres materiales e inmateriales $>$, <acciones $>$ y $<$ entidades abstractas $>$. La presencia de tal variedad semántica en la posición de $\mathrm{AE}$ y AI en los empleos rectos, figurados y gramaticalizados de andar es, asimismo, una prueba de la presencia de procesos de metaforización y metonimización en el desarrollo semántico de este verbo.

Destaca el importante número de documentaciones en las que aparece el uso gramaticalizado del verbo, si bien su empleo con valor figurado es el que dispone de una mayor variedad de significados. El sentido 'transcurrir un periodo de tiempo' resulta igualmente llamativo por la gran cantidad de documentaciones que presenta. Asimismo, los significados documentados por primera vez en el siglo XIII pertenecen tanto a valores rectos como a figurados y gramaticalizados. Sin embargo, es importante destacar que todos los empleos figurados y gramaticalizados son innovaciones romances, ya sean del siglo XIII o anteriores, y no estaban presentes en el étimo latino, según la bibliografía consultada. Este hecho confirma la importancia de la etapa de los orígenes del romance en el posterior desarrollo de la lengua española, puesto que es en este periodo cuando se produce la primera gran diversificación semántica del verbo andar.

Por último, se ha demostrado la influencia decisiva que ejercen las tradiciones discursivas en las que se inscriben los textos que albergan las ocurrencias del verbo estudiado. Mientras que algunos significados pueden aparecer prácticamente en cualquier tipo de documentos, la presencia de otros está condicionada por la tradición discursiva del texto en el que se encuentra el verbo. Este último es el caso de 'desplazarse', que es especialmente recurrente en los tratados de astrología; 'moverse una pieza por las casillas de un tablero', que se encuentra exclusivamente en una obra perteneciente al género de los libros de 
juegos; y 'actuar dejándose llevar por alguien o algo o bajo su mandato', cuyas ocurrencias pertenecen en su mayoría a documentos notariales, fueros y biblias romanceadas.

Queda patente, pues, la importancia del estudio de los verbos patrimoniales, en especial los llamados verbos de movimiento; un análisis que puede ser mucho más productivo si se acomete desde un punto de vista combinatorio, atendiendo a las relaciones léxicas y semánticas existentes entre las palabras. Asimismo, las tradiciones discursivas juegan un papel imprescindible en la evolución del léxico y en su uso por parte de los hablantes, por lo que deben ser tenidas en cuenta en investigaciones semánticas desde un punto de vista diacrónico y/o histórico. Todo ello contribuirá a reconstruir de forma más completa los orígenes de nuestra lengua, los cuales han condicionado de forma determinante su devenir histórico.

\section{BIBLIOGRAFÍA}

Alonso García, Amado (1974): "Sobre métodos: construcciones con verbos de movimiento", en A. Alonso García, Estudios lingüísticos, Madrid, Gredos, pp. 190-236.

Anderson, John M. (1971): The Grammar of Case. Towards a Localistic Theory, Cambridge, Cambridge University Press.

Behrens, Dietrich (1902): "Ital. Andare, firz. Aller", Zeitschrift für romanische Philologie, XXVI, pp. 243-244.

Bosque Muñoz, Ignacio (2004): "La direccionalidad en los diccionarios combinatorios y el problema de la selección léxica", en Teresa Cabré (ed.), Lingüística teòrica: anàlisi i perspectives I, Bellaterra, Universitat Autònoma de Barcelona, pp. 13-58.

Bossong, Georg (1982): "Las traducciones alfonsíes y el desarrollo de la prosa científica castellana", en Wido Hempel y Dietrich Briesemeister (eds.), Actas del Coloquio hispano-alemán Ramón Menéndez Pidal, Tübingen, Max Niemeyer, pp. 1-11.

Bustos Tovar, José Jesús de (2005 [2004]): "La escisión latín-romance. El nacimiento de las lenguas romances: el castellano", en Rafael Cano (coord.), Historia de la lengua española, Barcelona, Ariel, pp. 257-290.

Campos, Héctor (1999): "Transitividad e intransitividad", en Ignacio Bosque y Violeta Demonte (dirs.), Gramática descriptiva de la lengua española, II, Madrid, Espasa Calpe, pp. 1519-1574.

Cárcel Ortí, M. ${ }^{a}$ Milagros (1994) (ed.): Vocabulaire International de la Diplomatique, València, Universitat de València.

Castillo Herrero, M. ${ }^{a}$ Elena (2003): Inacusatividad y aspecto léxico en los verbos de movimiento. Estudio diacrónico, Girona, Documenta Universitaria.

CORDE = Real Academia Española, Banco de datos CORDE. Corpus diacrónico del español, $<$ http://www.rae.es>, [fecha de consulta: 21/06/2010].

Coseriu, Eugenio (1977): "Sobre las llamadas construcciones con verbos de movimiento: un problema hispánico", en Eugenio Coseriu, Estudios de lingüística románica, Madrid, Gredos, pp. 70-78.

Crego García, M. ${ }^{a}$ Victorina (1994): "Construcciones libres vs. perífrasis verbales en los verbos de movimiento del español medieval", Verba: Anuario galego de filoloxía, 21, pp. 207-224.

Crego García, M. ${ }^{a}$ Victorina (1998): "Un caso de valencia ampliada o mixta en el español medieval”, en Claudio García et al. (coords.), Actas del IV Congreso Internacional de Historia de la Lengua Española, I, Logroño, Universidad de La Rioja, pp. 445-456. 
Crego García, M. ${ }^{a}$ Victorina (2000): El complemento locativo en español. Los verbos de movimiento y su combinatoria sintáctico-semántica, Santiago de Compostela, Universidade de Santiago de Compostela.

Crego García, M. ${ }^{a}$ Victorina (2002): "Análisis multidimensional de dos archilexemas verbales emblemáticos: ir y andar", en M. ${ }^{a}$ Teresa Echenique y Juan P. Sánchez (coords.), Actas del V Congreso Internacional de Historia de la Lengua Española, Madrid, Gredos, pp. 1991-2006.

DECH $=$ Corominas, Joan y Pascual, José Antonio (2012 [1980-1991]): Diccionario crítico etimológico castellano e hispánico, edición en CD-ROM, Madrid, Gredos.

DHLF = Rey, Alain (1993) (dir.): Dictionnaire Historique de la Langue Française, Paris, Dictionnaires Le Robert.

DRAE = Real Academia Española (2001): Diccionario de la Lengua Española, 22 ${ }^{\mathrm{a}}$ ed., $<$ http://www.rae.es> [fecha de consulta: 10/12/2010].

Eslava Heredia, Cristina (2008): "Pautas gramaticales de verbos de movimiento que concurren con diversas preposiciones en el español del siglo XIII", en Concepción Company y José G. Moreno de Alba (coords.), Actas del VII Congreso Internacional de Historia de la Lengua Española, I, Madrid, Arco/Libros, pp. 569-581.

Fernández-Ordóñez, Inés (2005 [2004]): "Alfonso X el Sabio en la historia del español", en Rafael Cano (coord.), Historia de la lengua española, Barcelona, Ariel, pp. 381-422.

FEW = Wartburg, Walther von (1948-1998 [1888-1971]): Französisches Etymologisches Wörterbuch: eine darstellung des galloromanischen sprachschatzes, Basel, Zbinden Druck und Verlag.

Fillmore, Charles (1968): "The case for case", en Emmon Bach y Robert T. Harms (eds.), Universals in Linguistic Theory, New York, Holt, Rinehart y Winston, pp. 1-88, <http://www. eric.ed.gov/PDFS/ED019631.pdf> [fecha de consulta: 06/09/2010].

Gaffiot, Félix (1934): Dictionnaire illustré latin français, Paris, Librairie Hachette.

Galán Rodríguez, Carmen (1988): "Los verbos de movimiento en la prosa alfonsî", en Manuel Ariza et al. (eds.), Actas del I Congreso Internacional de Historia de la Lengua Española, I, Madrid, Arco/Libros, pp. 357-362.

Galmés de Fuentes, Álvaro (1985): "Alfonso X el Sabio y la creación de la prosa literaria castellana”, en José Mondéjar y Jesús Montoya (eds.), Estudios alfonsíes. Lexicografía, estética y política de Alfonso el Sabio, Granada, Universidad de Granada, pp. 33-58.

Garcés Gómez, M. ${ }^{a}$ Pilar (1992): "Valores y usos de algunas construcciones verbales en español", en Manuel Ariza (coord.), Actas del II Congreso Internacional de Historia de la Lengua Española, I, Madrid, Pabellón de España, pp. 437-444.

García Padrón, Dolores (1990): "En torno al llamado "proceso de desemantización”", Filología Románica, 7, pp. 241-253.

García Pérez, Rafael (2003-2004): "La organización de las acepciones en un diccionario histórico", Revista de Lexicografía, X, pp. 103-131.

García Pérez, Rafael (2005): “¿Desde cuándo se cometen delitos? Relaciones entre léxico y sintaxis en la evolución histórica de la lengua del derecho penal", en Luis Santos (coord.), Palabras, norma y discurso. En memoria de Fernando Lázaro Carreter, Salamanca, Universidad de Salamanca, pp. 509-520.

García Pérez, Rafael (2007): ¿Qué hacíamos y qué hacemos? El verbo hacer en la historia del español, San Millán de la Cogolla, Cilengua.

Gómez Redondo, Fernando (1998): Historia de la prosa medieval castellana, I. La creación del discurso prosístico: el entramado cortesano, Madrid, Cátedra.

González Ollé, Fernando (1978): "El establecimiento del castellano como lengua oficial", Boletín de la Real Academia Española, LVIII, pp. 229-280.

Grandgent, Charles H. (1963): Introducción al latín vulgar, Madrid, CSIC.

Green, John N. (1982): "The status of the Romance auxiliaries of voice", en Nigel Vincent y Martin Harris (eds.), Studies in the Romance Verb, London, Croom Helm, pp. 97-138. 
Hernández Navarro, Francisco J. (1999): "Sobre los orígenes del español escrito", Voz y Letra, X, 2, pp. 133-166.

Julià Luna, Carolina y Ana Paz Afonso (2012): "Somatismos con la voz mano y verbos de desplazamiento en el Diccionario de Autoridades: estudio histórico y cognitivo", en Emilio Montero Cartelle (ed.), Actas del VIII Congreso Internacional de Historia de la Lengua Española, I, Santiago de Compostela, Meubook, pp. 1445-1459.

Koch, Peter y Wulf Oesterreicher (2007): Lengua hablada en la Romania: español, francés, italiano, Madrid, Gredos.

Kock, Josse De (1975): "Pour une nouvelle définition de la notion d'auxiliarité", Linguistique, XI, 2, pp. 81-92.

Lakoff, George y Mark Johnson (1986): Metáforas de la vida cotidiana, Madrid, Gredos.

Lapesa Melgar, Rafael (2008 [1981]): Historia de la lengua española, Madrid, Gredos.

Lyons, John (1971 [1968]): Introducción en la lingüística teórica, Barcelona, Teide.

Lyons, John (1975): "Deixis as the source of reference", en Edward L. Keenan (ed.), Formal semantics of natural language: papers from a colloquium sponsored by the King's College Research Centre, Cambridge, Cambridge University Press, pp. 61-83.

Malkiel, Yakov (1947): "The Romance Word Family of Latin AMBĀGO", Word, III, pp. 59-73.

Martín Zorraquino, M. ${ }^{a}$ Antonia (1993): "Ir e irse en el Cantar de Mio Cid", en Departamento de Historia Medieval (ed.), Aragón en la Edad Media: Homenaje a la profesora emérita María Luisa Ledesma Rubio, X-XI, Zaragoza, Universidad de Zaragoza, pp. 575-588.

Martín Zorraquino, M. a Antonia (1998): "Venir/venirse en el Cantar de Mio Cid", en Claudio García et al. (coords.), Actas del IV Congreso Internacional de Historia de la Lengua Española, I, Logroño, Universidad de La Rioja, pp. 581-596.

Matthies, Werner (1933): Die aus den intransitiven Verben der Bewegung und dem Partizip des Perfekts gebildeten Umschreibungen im Spanischen, Leipzig, Jena, W. Gronau.

Meier, Harri (1933): "Está enamorado - anda enamorado", Volkstum und Kultur der Romanen, VI, pp. 301-306.

Melis Van Eerdewegh, Chantal (2006): "Verbos de movimiento. La formación de los futuros perifrásticos", en Concepción Company Company (dir.), Sintaxis histórica de la lengua española. Primera parte: La frase verbal, II, México, Universidad Nacional Autónoma de México, Fondo de Cultura Económica, pp. 873-968.

Mendikoetxea Pelayo, Amaya (1999): "Construcciones inacusativas y pasivas", en Ignacio Bosque y Violeta Demonte (dirs.), Gramática descriptiva de la lengua española, II, Madrid, Espasa Calpe, pp. 1575-1630.

Montaner Frutos, Alberto (2000) (ed.): Cantar de Mio Cid, Barcelona, Crítica.

Morimoto, Yuko (2001): Los verbos de movimiento, Madrid, Visor Libros.

Paz Afonso, Ana (2008): Modelo de variación diacrónica: el verbo andar entre los siglos VIII y XIII, Bellaterra, Departamento de Filología Española, trabajo inédito de máster, Universidad Autónoma de Barcelona.

Paz Afonso, Ana (2009): "Análisis contrastivo y evolución semántica del verbo andar", en Carolina Julià y Laura Romero (coords.), Tendencias actuales en la investigación diacrónica de la lengua. Actas del VIII Congreso Nacional de la Asociación de Jóvenes Investigadores de Historiografía e Historia de la Lengua (AJIHLE), Barcelona, Universidad de Barcelona, pp. 423-432.

Paz Afonso, Ana (2010): "El verbo andar en expresiones temporales: días andados y días por andar", en María Teresa Encinas et al. (coords.), Ars longa. Diez años de AJIHLE (Asociación de Jóvenes Investigadores de Historiografía e Historia de la Lengua Española), I, Buenos Aires, Voces del sur, pp. 369-382, V <http://www.academia.edu/attachments/31307383/download_file> [fecha de consulta: 19/06/2013].

Paz Afonso, Ana (2013): "Entrar en batalla: Aproximación a las relaciones léxicas entre el verbo entrar y el léxico del siglo XIII", en Emili Casanova et Cesáreo Calvo (eds.), Actes du XXVI Congrès International de Linguistique et de Philologie Romanes (València, 6-11 de septembre de 2010), IV, Berlin, De Gruiter, pp. 327-337. 
Paz Afonso, Ana (en prensa a): "Efectos de prototipicidad y estudio histórico del léxico: análisis semántico de entrar en el s. XIII", en José María García Martín (dir.), Actas del IX Congreso Internacional de Historia de la Lengua Española (Cádiz, 10-14 de septiembre de 2012).

Paz Afonso, Ana (en prensa b): "La variación polisémica del verbo salir en el siglo XIII: estudio histórico y cognitivo", en José Francisco Val Álvaro et al. (dirs.), Actas del X Congreso Internacional de Lingüística General (Zaragoza, 18-20 de abril de 2012).

Pérez Saldanya, Manuel (2008): "Entre ir y venir, del léxico a la gramática", en Concepción Company y José G. Moreno de Alba (coords.), Actas del VIII Congreso Internacional de Historia de la Lengua Española, I, Madrid, Arco/Libros, pp. 159-184.

Pottier, Bernard (1961): "Sobre el concepto de "verbo auxiliar"”, Nueva Revista de Filología Hispánica, XV, pp. 325-331.

REW = Meyer-Lübke, Wilhelm (1968): Romanisches Etymologisches Wörterbuch, Heidelberg, Winter.

Rice, Carl C. (1904): "The Etymology of the Romance Words for 'To Go", Publications of the Modern Language Association of America, XIX, 2, pp. 214-233.

Roca Pons, José (1954): "Sobre el valor auxiliar y copulativo del verbo andar", Archivum, IV, pp. 166-182.

Rohlfs, Gerhard (1920): "Zur Lokalisierung von it. Andare", Zeitschrift für romanische Philologie, XL, pp. 337-339.

Sánchez Jiménez, Santiago U. (2011): “Andanzas del verbo andar", en Carsten Sinner, José Luis Ramírez y M. ${ }^{a}$ Jesús Torrens (coords.), Tiempo, espacio y relaciones espacio-temporales desde la perspectiva de la Lingüística histórica, San Millán de la Cogolla, Cilengua, pp. 227263.

Sarrazin, Sophie (2011): "Una semántica del espacio al servicio del aspecto: estar, ir, venir, andar, auxiliares de perífrasis verbales en español", en Juan Cuartero, Luis García y Carsten Sinner (coords.), Estudios sobre perífrasis y aspecto, München, Peniope, pp. 180-198.

Schmelicek, Hans (1930): Die Gerundialumschreibung im Altspanischen zum Ausdruck von Aktionsarten, Hamburg, Romanisches Seminar.

Schuchardt, Hugo (1902): "Etymologische Probleme und Prinzipen", Zeitschrift für Romanische Philologie, XXVI, pp. 385-452.

Serradilla Castaño, Ana (2011): “Apuntes sobre fraseología histórica: las expresiones figuradas con verbos de movimiento en español medieval", Círculo de Lingüística Aplicada a la Comunicación, XLV, pp. 21-54, <http://www.ucm.es/info/circulo/no45/serradilla.pdf> [fecha de consulta: 20/06/2010].

Spaulding, Robert K. (1925-1928): "History and Syntax of the Progressive Construction in Spanish", University of California Publications in Modern Philology, XIII, pp. 229-284.

Steiger, Arnald (ed.) (1941): Libros de acedrex, dados e tablas: Das Schachzabelbuch König Alfons des Weisen, Alfonso X el Sabio, Genève, Droz.

Suárez Fernández, Mercedes (1992): "Sintaxis de los verbos de movimiento en construcción intransitiva en el Poema del Mio Cid", en Manuel Ariza et al., (coords.), Actas del II Congreso Internacional de Historia de la Lengua Española, I, Madrid, Pabellón de España, pp. 841-858.

Väänänen, Veiko (2003 [1985]): Introducción al latín vulgar, Madrid, Gredos.

Yllera Fernández, Alicia (1980): Sintaxis histórica del verbo español. Las perífrasis medievales, Zaragoza, Universidad de Zaragoza.

Fecha de recepción: 30 de mayo de 2011

Fecha de aceptación: 31 de enero de 2012 